and it summarized the aim to which his whole life had been devoted. Had it not been for the fact that he remained primarily a biologist to the end, thus lessening somewhat the parallelism between their lives, we might well have come to think of him as the Russian W. B. Hardy. JosepH Nefdham.

\section{Mr. I. O. Griffith}

By the sudden death of Mr. I. O. Griffith on September 22, the day before his sixty-first birthday, the University of Oxford, and especially the science faculties, have lost more than can be easily measured. As member of the Hebdomadal Council, vice-chairman of the General Board, chairman of the Board of Faculty, treasurer of the Natural Science Club, he held a key position in the scientific administration in the University. Whatever the branch of science and however remote from his own special loves, mathematics and physics, he could always be counted upon to make every effort to help to bring a project to fruition. He will be indeed difficult to replace in the councils of the University.

After his distinguished flying work, mainly on the navigational side, in the R.A.F., during 1914-18, which earned him the Air Force Cross, he returned to Oxford as senior demonstrator in the Clarendon Laboratory. Always keenly interested in teaching he was mainly responsible for building up the advanced course and organizing the expansion of the Department which trebled or quadrupled its activities during his period of office. His work on the measurement of temperature in the high-pressure are led on to the well-known monograph on photographic photometry published by himself and Dr. Dobson. But his conscientious devotion to his students' interest left him scant time for research, and it is in their activities and records that his main contributions to physics will be discerned.

The departure of many of his younger colleagues since the outbreak of war left him with more teaching than ever to do. Always ready to help, he had one task after another thrust upon him. True to his old service, he accepted the important and onerous duty of looking after the Air Force cadets in the University and organizing their teaching. No better choice could have been made, and the immediate success of the scheme is evidence of his tireless work and administrative ability.

It is impossible to describe Griffith's peculiar personal charm in words. Invariably cheerful and friendly, he could be relied on to face an acrimonious debate on the Board of Faculty or a critical situation in a crucial golf match with equal adequacy. Free from any thought of self, he devoted all his efforts to the advantage of his pupils and his colleagues. A keen member of his College, he never allowed parochial patriotism to over-ride his devotion to the interests of the University. His balanced judgment confuted those who delight to paint the average don as a creature of moods and foibles with an outlook bounded by curricula and examinations. Void of the glitter and clash of more metallic personalities he did great work for his University and his country which will bear fruit long after the more strident voices, which so easily gain popular acclaim, have died away.

\section{Prof. R. B. Wild}

IT is with regret that we record the death on October 7 of Prof. R. B. Wild, emeritus professor of materia medica and therapeutics in the University of Manchester.

Educated at Owens College, Prof. Wild was associated with Manchester throughout his active career. After serving for a time as an assistant lecturer in the Department of Pathology he transferred his affection to the subjects of pharmacology and therapeutics and joined the staff of the late Prof. D. J. Leech. The two men developed an active Department in which important work in experimental pharmacology was done, the most significant being a study of the effects of the nitrites upon the circulatory system. One of the results of their researches was the recognition of amyl nitrite as an official preparation.

On the death of Leech in 1900, Wild was elected to the chair and in 1919 became the first whole-time Leech professor of materia medica and therapeutics. When in consulting practice, Wild was recognized as an authority on dermatology and he wrote a number of papers on diseases of the skin. For many years he was intimately associated with the Christie Cancer Pavilion and Home; he was responsible for the medical side of the work and played a leading part in the administration of the institution. Throughout his teaching career he was untiring in his efforts to develop and improve the Faculty of Medicine and his contributions to medical education were of the greatest value. For a time he was dean of the Medical School and the representative of the University on the General Medical Council. As a member of Senate he took a prominent part in general University affairs and acted for a period as one of the pro-vicechancellors. He retired in 1927, when he ceased to live in Manchester, but still kept in touch with the University and city which he served so conscientiously and well. J. S. B. STOpFord.

WE regret to announce the following deaths :

Mr. W. A. Bailey, chief conservator of forests, Indian Forest Service, on July 14.

Mr. Norman de Garis Davies, the well-known Egyptologist, on November 5, aged seventy-six.

Dr. Walter Granger, curator of fossil mammals in the American Museum of Natural History, on September 6, aged sixty-eight.

Prof. C. M. Sparrow, professor of physics in the University of Virginia, on August 30, aged sixty-one.

Prof. T. H. Taliaferro, professor of mathematics in the University of Maryland, on September 25, aged seventy. 